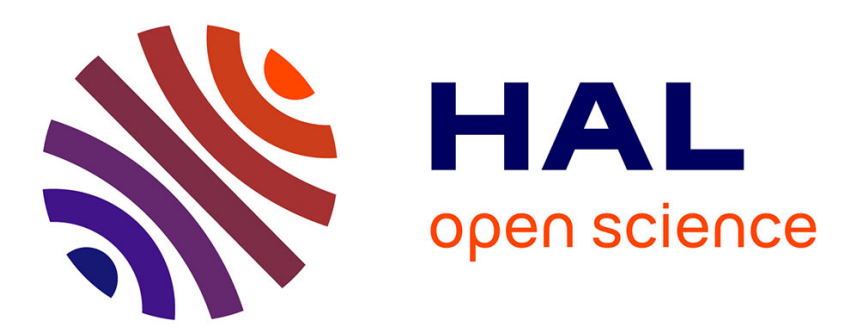

\title{
Novel heterozygous mutation in ANO3 responsible for craniocervical dystonia
}

\author{
Morgane Miltgen, Arnaud Blanchard, Hélène Mathieu, Alexandre Kreisler, \\ Jean-Pierre Desvignes, David Salgado, Agathe Roubertie, Laura Barre, Ghadi \\ Rai, Veronique Blanck, et al.
}

\section{To cite this version:}

Morgane Miltgen, Arnaud Blanchard, Hélène Mathieu, Alexandre Kreisler, Jean-Pierre Desvignes, et al.. Novel heterozygous mutation in ANO3 responsible for craniocervical dystonia. Movement Disorders, 2016, 31 (8), pp.1251-1252. 10.1002/mds.26717 . hal-01670172

\section{HAL Id: hal-01670172 https://hal.science/hal-01670172}

Submitted on 21 Dec 2017

HAL is a multi-disciplinary open access archive for the deposit and dissemination of scientific research documents, whether they are published or not. The documents may come from teaching and research institutions in France or abroad, or from public or private research centers.
L'archive ouverte pluridisciplinaire HAL, est destinée au dépôt et à la diffusion de documents scientifiques de niveau recherche, publiés ou non, émanant des établissements d'enseignement et de recherche français ou étrangers, des laboratoires publics ou privés. 


\section{Novel Heterozygous Mutation in ANO3 Responsible for Craniocervical Dystonia}

To determine the genetic basis of dystonia, we performed exome sequencing in 4 patients from a multigenerational family from Flemish origin, with no TOR1A or THAP1 mutations (Fig. 1). In the proband (III-1), the age of onset for movement disorders was 53 years. She complained mainly of involuntary eyelid movements. Neurological examination showed severe blepharospasm accompanied by apraxia of eyelid opening, a mild oromandibular and cervical dystonia (right, painful torticollis). Blepharospasm improved with a high dose of botulinum toxin A (OnabotulinumtoxinA, 30 units to each side every 3 months). The proband's mother (II-1) presented movement disorders from the age of 40 . Neurological examination showed a blepharospasm and a cervical dystonia. According to the proband, her grandmother (I-2) and her grandmother's

*Correspondence to: Dr. Gwenaelle Collod-Béroud, INSERM UMR_S910, Medical Genetics and Functional Genomics, Faculté de Médecine la Timone, 27 Bd Jean Moulin, 13385 Marseille Cedex 05, France; E-mail: gwenaelle.collod-beroud@inserm.fr

Relevant conflicts of interest/financial disclosures: Nothing to report. Full financial disclosures and author roles may be found in the online version of this article. two brothers (I-6 and I-8) had displayed jerky, involuntary movements of the head. This could not be confirmed by a clinical examination because all were deceased at the time of the study. One of the proband's brothers (III-4) is being treated for cervical dystonia, which began at 40 years old, without additional dystonic symptoms. In another brother (III-6), clinical examination at 68 years of age showed a postural tremor of the upper limbs, without additional neurological symptoms. Onset age is unknown because III-6 had not noticed his tremor before the examination. An isolated, postural tremor of upper limbs was also found in two sons of the proband (IV-1 and IV-4) beginning in childhood and adolescence, respectively. The tremor did not fit with the specific pattern of dystonic tremor in any of the 3 patients (III-6, IV-1, and IV-4). Based on neurological observations, this familial tremor is concordant with physiological tremor or essential tremor, although druginduced tremor cannot be ruled out for IV-1, given that he has received dopamine antagonist treatment from childhood for behavioral disorders associated with mental retardation. Therefore, we concluded that tremor and dystonia are two distinct entities in this family. Finally, neurological findings were normal for IV-10 (35 years old).

Exome sequencing identified the c.1969G $>$ A (p.Ala657Thr) variant in ANO3, a gene associted with dystonia (see Supplementary Data). ${ }^{1}$ The variant in exon 19 is carried by all 3 affected patients (II-1, III-1, and III-4) presenting neither tremor nor myoclonus, one asymptomatic family member (IV-10), but also by IV-1, who presented with postural tremor that may have been drug induced. This variant is not reported in the Exome Aggregation Consortium (ExAC). It involves a highly conserved residue and is predicted as disease causing by UMD-Predictor ${ }^{2}$ and MutationTaster. ${ }^{3}$ Twelve ANO3 variants have previously been described in dystonia cases. ${ }^{1,4,5}$ The c.1969G $>$ A mutation is the first variant to be located in a transmembrane domain (domain-5) of the anoctamin 3 protein encoded by ANO3 and is predicted to switch hydrophobicity of this segment. ${ }^{6}$ No pathogenic variant was identified in other dystonia genes.

To conclude, we report a novel c.1969G $>$ A mutation in the ANO3 gene in a family presenting with a typical dystonia phenotype consistent with previous reports ${ }^{4,5,7}$ : onset mainly after the fourth decade, begins as cervical dystonia, but evolves to segmental dystonia, without leg involvement or any generalized dystonia.

Morgane Miltgen, MS, ${ }^{1}$ Arnaud Blanchard, PhD, ${ }^{1}$ Hélène Mathieu, MS, ${ }^{1}$ Alexandre Kreisler, MD, PhD, ${ }^{2,3}$ Jean-Pierre-Desvignes, MS, ${ }^{1}$ David Salgado, $\mathrm{PhD},{ }^{1}$ Agathe Roubertie, MD, PhD, ${ }^{4}$ Laura Barre, MS, ${ }^{1}$ Ghadi Rai, MS, ${ }^{1}$ Veronique Blanck, MS, ${ }^{5}$ Melissa Frederic, $\mathrm{PhD},{ }^{1}$ Xavier Douay, $\mathrm{MD},{ }^{2}$ Ronald Mazzoleni, MD, ${ }^{2}$ Pierre Charpentier, $\mathrm{MD},{ }^{6}$ Victoria Gonzalez, MD, PhD, ${ }^{7}$ Alain Destee, $\mathrm{MD}, \mathrm{PhD},{ }^{2,3}$ Christophe Beroud, PharmD, PhD, ${ }^{1,5}$ and Gwenaelle Collod-Beroud, $\mathrm{PhD}^{1}$

${ }^{1}$ Aix Marseille Univ, INSERM, GMGF, Marseille, France;

${ }^{2}$ Université de Lille, CHRU de Lille, Service de Neurologie et Pathologie du Mouvement, Lille, France; ${ }^{3}$ INSERM UMR-S1172, Lille, France; ${ }^{4}$ CHRU Montpellier, Service de Neuro-pédiatrie, Höpital Gui de Chauliac, Montpellier, France; Institut des Neurosciences de Montpellier, INSERM U1051, Université de Montpellier, BP 74103, Montpellier, 


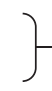

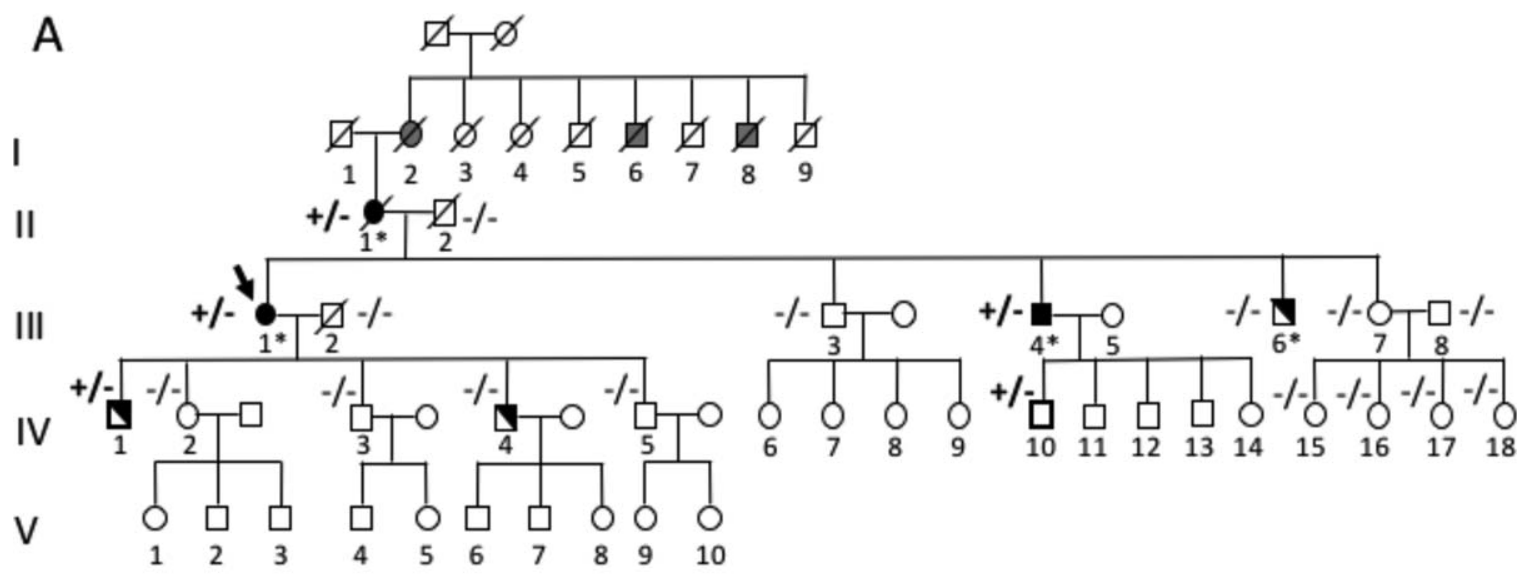

B

\begin{tabular}{ccccccc} 
Patient & Sex & Age & Age of onset & $\begin{array}{c}\text { Site of } \\
\text { onset }\end{array}$ & $\begin{array}{c}\text { Age at last } \\
\text { examination }\end{array}$ & Clinical description \\
\hline II-1* & F & 90 & 40 & UK & 87 & $\begin{array}{c}\text { Cervical dystonia, } \\
\text { blepharospasm }\end{array}$ \\
\hline III-1* & F & 73 & 53 & Eyelids & 72 & $\begin{array}{c}\text { Blepharospasm, cervical dystonia, } \\
\text { oromandibular dystonia }\end{array}$ \\
\hline III-4* & M & 64 & 40 & Neck & 51 & Cervical dystonia \\
\hline III-6* & M & 71 & UK & Upper limbs & 68 & Postural tremor \\
\hline IV-1 & M & 51 & Childhood & Upper limbs & 50 & Postural tremor \\
\hline IV-4 & M & 47 & Adolescence & Upper limbs & 45 & Postural tremor \\
\hline IV-10 & M & 35 & - & - & 35 & Asymptomatic \\
\hline
\end{tabular}

FIG. 1. Pedigree with the c.1969G > A (p.Ala657Thr) mutation in the ANO3 gene. (A) Pedigree structure of the studied family. Symbols filled in black represent patients presenting with dystonia; Symbols half-filled in black represent patients presenting with isolated tremor; Symbols filled in grey represent patients reported with cervical dystonia (not examined). +/- ANO3 heterozygous mutation carrier. -/- Homozygous wild-type allele carrier. Arrow indicates proband. (B) Detailed clinical description. UK: Unknown. Individuals on whom WES was performed are indicated with a star. Exome sequencing analysis of the proband's brother (III-6) presenting with isolated tremor does not identify any pathogenic variation in the known tremor-causing genes (DRD3, FUS, SNC4A and TENM4).

France; ${ }^{5}$ Hôpital La Timone, Département de Génétique Médicale, Marseille, France; ${ }^{6} \mathrm{CH}$ Béthune, Service de Neurologie, France; ${ }^{7} \mathrm{CHU}$ Montpellier, Hôpital Gui de Chauliac, Service de Neurochirurgie, Montpellier, France

\section{References}

1. Charlesworth G, Plagnol V, Holmstrom KM, et al. Mutations in ANO3 cause dominant craniocervical dystonia: ion channel implicated in pathogenesis. Am J Hum Genet 2012;91:10411050.

2. Salgado D, Desvignes JP, Rai G, et al. UMD-Predictor: a high throughput sequencing compliant system for pathogenicity prediction of any human cDNA substitution. Hum Mutat 2016;37:439-446.

3. Schwarz JM, Cooper DN, Schuelke M, et al. MutationTaster2: mutation prediction for the deep-sequencing age. Nat Methods 2014;11:361-362.
4. Ma LY, Wang L, Yang YM, et al. Mutations in ANO3 and GNAL gene in thirty-three isolated dystonia families. Mov Disord 2015;30:743-744.

5. Zech M, Gross N, Jochim A, et al. Rare sequence variants in ANO3 and GNAL in a primary torsion dystonia series and controls. Mov Disord 2014;29:143-147.

6. Paulet D, Claustres M, Béroud C. Hydrophobic pulses predict transmembrane helix irregularities and channel transmembrane units. BMC Bioinformatics 2011;12:135

7. Stamelou M, Charlesworth G, Cordivari C, et al. The phenotypic spectrum of DYT24 due to ANO3 mutations. Mov Disord 2014; 29:928-934.

\section{Supporting Data}

Additional Supporting Information may be found in the online version of this article at the publisher's web-site. 